\title{
A FÖLDRAJZI ISMERETEK TERJESZTÉSÉNEK ÚJ SZÍNTEREI: A GEOPARKOK
} THE GEOPARKS, AS NEW STAGES FOR DISSEMINATING GEOGRAPHICAL KNOWLEDGE

\section{HORVÁTH GERGELY}

Eötvös Loránd Tudományegyetem TTK

horvger@caesar.elte.hu

\begin{abstract}
For the majority of mankind "nature conservation" means only the protection of the flora and fauna and - in a wider sense - that of the biodiversity. It did not become widely known that also the inanimate elements of the nature should be protected. At the second half of 20th century started a movement in the earth sciences for making known for the public the importance of the geological and geomorphic values, of which summing name became the geoheritage, and also the notion of the geosites - places, where geoscientific values can be found - has been introduced. Moreover, for making known with the public the geoheritage a new institution-type has been established, the geopark. However, in spite this intention the main aim of the geopark is not showing, but the regional development of the area of the geopark (and its vicinity), especially due to the geotourism inspired by the geoheritage. Since the establishment of the first four European geoparks in 2000, the geopark movement widely distributed and recently it is co-ordinated by the Global Geopark Network, which belongs to the UNESCO. Nowadays is very difficult to be member of the Network, it needs a long application process and the title can be obtained only for five years, thereafter the usage of the title will be strictly reconsidered. In 2019 there are 140 geoparks in 38 countries, among them two Hungarian, the Novohrad-Nógrád and the Bakony-Balaton Geopark.
\end{abstract}

Keywords: geopark, geoheritage, geosite, nature conservation, geographical education

\section{Földtudományi természeti értékek és védelmük}

A természetvédelem a legtöbb ember számára alapvetően - vagy éppen kizárólag - az élővilág védelmét jelenti még ma is. Látván az élővilágban végbemenő fajkihalásokat és az élővilág sokféleségének (a biodiverzitásnak) rohamos csökkenését, nem vitatható, hogy az élő természet védelme, elemeinek megörzése az emberiség szempontjából létfontosságú. Ám emellett sajnos többnyire kevés figyelem jut az élettelen természetre, annak védelme jóval kevésbé tudatosodott, sokszor még a hivatásos természetvédelmi szervezetek esetében is háttérbe szorult. Holott az élettelen természet elemei éppen olyan értékesek, mint az élővilágé, és ugyanúgy veszélyeztetettek, sérülékenyek, tehát védelemre szorulnak.

Melyek is ezek az elemek? Leginkább a kőzetburok (litoszféra) elemei, az ásványok, a kőzetek, a kőzetrétegek, valamint a belső és külső erők - vagy esetleg Földön kívüli (exterresztrikus) jelenségek - létrehozta, általában felszínen lévő képződmények, 
felszínformák. Másodsorban a vízburok (hidroszféra) elemei, közöttük a felszíni (folyók, tavak, források) és felszín alatti (rétegvíz, karsztvíz) vizek. És ide sorolhatók, ám legkevésbé megbecsültek a talajtakaró (pedoszféra) elemei, a talajok. Ezek olyan elemek, amelyekkel elsősorban a földtudományok, különösen a földtan (geológia) és a felszínalaktan (geomorfológia) foglalkoznak. Bár természetvédelmi jelentőségüket természetesen már korábban is sokan felismerték (Burek, C. V. - Prosser. C. D. 2008), mégis leginkább csak a 20. század második felében jelent meg az a gondolat, hogy ezek éppen úgy a Föld „örökségét” alkotják, mint az élővilág vagy az épített környezet elemei, s került a köztudatba a földtudományi örökség - a nemzetközi irodalomban geoheritage -, illetve ennek nyomán a földtudományi természetvédelem fogalma (KIss G. 1996, Tardy J. et al. 2006, Tardy J. - Szarvas I. 2008, Wimbledon, W. A. P. - SmithMeyer, S. 2012). Ezeknek az elemeknek egy jelentős része tudományos, kulturális, oktatási vagy éppen esztétikai szempontból kiemelkedő jelentőségü érték, amelyeket angol nyelven geosite-nak (WIMBLEDON, W. A. P. 1996), német nyelven Geotopnak neveznek; rövid magyar nyelvű kifejezést nem sikerült alkotni rá, ezért újabban az ilyen értékekre, illetve azok helyszínére a némethez hasonló alakú, könnyen kimondható, ógörög nyelvi elemekből kialakított geotóp kifejezést használjuk. Nyilvánvaló, hogy elméleti jelentőségükön túl ezeknek a geotópoknak és az azokat kialakító folyamatoknak, földtudományi jellegzetességeiknek a bemutatása kiváló eszköz lehet a földrajztanár számára is a tanítási folyamatban szereplő fogalmak, jelenségek élményszerü, érdeklődést felkeltő megismertetésére.

Mielőtt a - többek között a geotópok bemutatását is szolgáló - geoparkok fogalmát ismertetnénk, érdemes azért megemlíteni, hogy bár a földtudományi természetvédelem csak néhány évtizede építette ki a maga intézményrendszerét, mégis a természetvédelem egyik legrégebben ismert jelképe már földtudományi értékeinek köszönhette hírnevét. Az UNESCO Világörökségévé is nyilvánított Yellowstone Parkról (Lotz, J. - SchÜR MANN, J. 1998) van szó, amely - Észak-Amerika egész nyugati részéhez hasonlóan - a 19. század végéig jóformán ismeretlen volt az emberiség előtt. Pedig már a század elején érkeztek hírek róla azt követően, hogy a Meriwether Lewis (1774-1809) és William Clark (17701838) által vezetett Lewis-Clark-expedíció 1804-1806 között a Mississippi és a Missouri összefolyásától a Columbia torkolatáig terjedően átszelte az akkor még ismeretlen Préri-fennsíkot, valamint az Észak-amerikai-Kordillerák láncait és medencéit. Ennek az expedíciónak tagja volt John Colter ( 1774-1813) is, aki az expedíciót elhagyva 1806ban prémkereskedőkhöz csatlakozva a Sziklás-hegység ismeretlen tájára vetődött és 1807 telén elsőként haladt át a mai park egy részén, felfedezve a különleges geotermális 
jelenségeket (Anglin, R. M. - MorRis, L. E. 2016). 1809-ben egy indiánokkal vívott összecsapásban megsebesült, ám abból felépült és keletre visszatérve beszámolt a „pokolbéli kénes és tüzes” helyről. Nem hittek neki, de aztán egyre több hasonló beszámoló érkezett „Colter poklából”: forrásban lévő sárról, gőzölgő folyókról, forróvíz-szökőkutakról (1. kép), megkövesedett fákról stb. Ennek ellenére évtizedek teltek el az első tudományos feltárásig, amely Ferdinand Vandeveer Hayden (1829-1887) geológus nevéhez füződik. 1870-es kutatóútja után átfogó jelentést készített a Yellowstone-ról, amelyet William Henry Jackson nagyméretü fotográfiái és Thomas Moran látványos festményei illusztráltak. Ennek nyomán - és egy másik expedíció tagjának, a montanai író és jogász Cornelius Hedges-nek a javaslatára - az amerikai Kongresszus kivonta a régiót az elárverezendő területek közül, és a területnek kiemelt védettséget biztosítva 1872. március 1-jén Ulysses S. Grant elnök aláírta a Yellowstone Nemzeti Parkot létrehozó törvényt, ezzel megszületett a Föld legelső nemzeti parkja.

A földtudományi természeti értékek védelmére és bemutatására sokfajta intézményesített területtípus létezik a Föld egyes országaiban, amelyek persze - nevezéktanukon túl

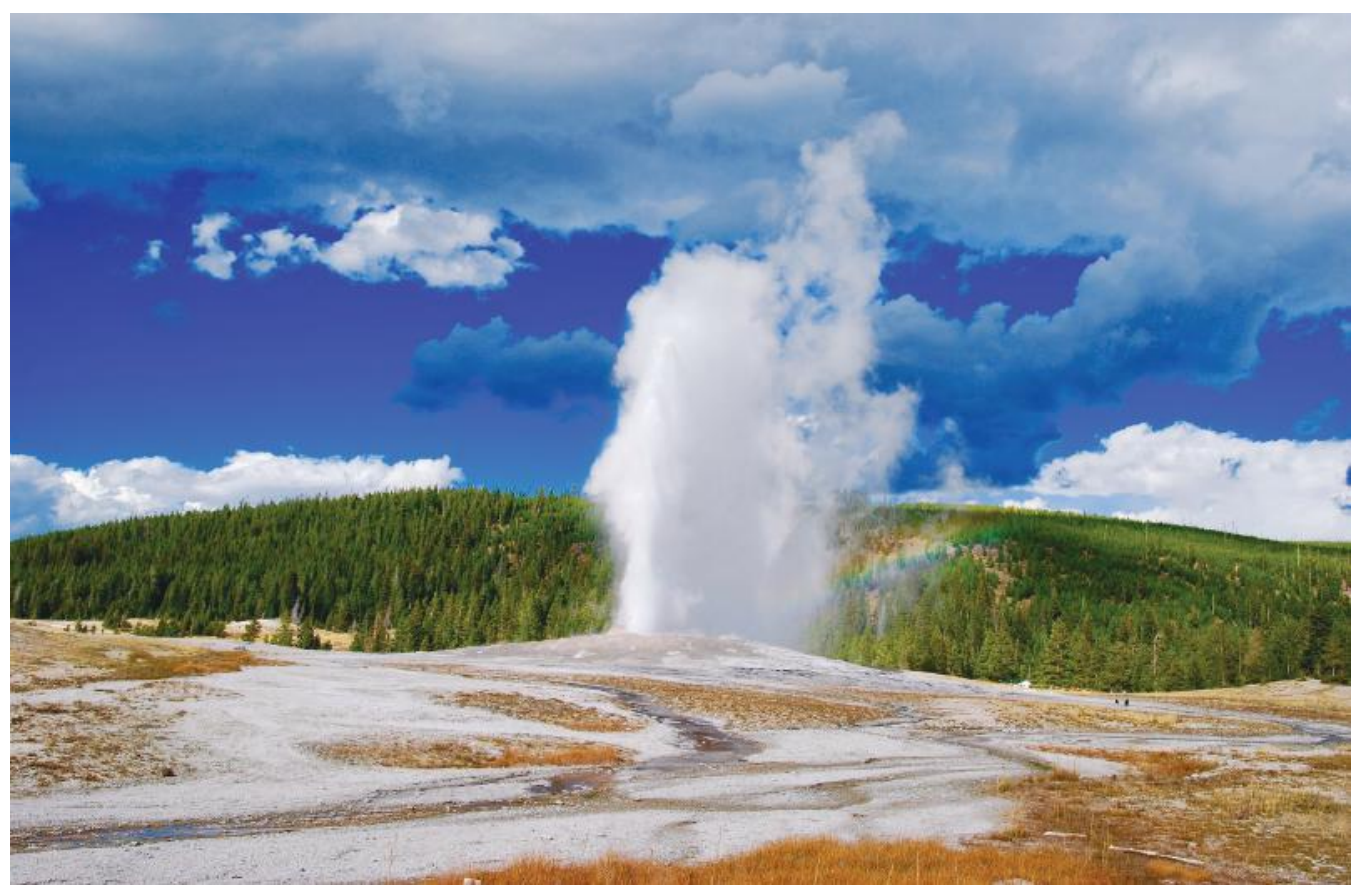

1. kép. Gejzír kitörése a Yellowstone Nemzeti Parkban (forrás: https://www.rmrentals.com/area-guide/ yellowstone-national-park) 
- jelentősen különbözhetnek egyrészt a védelem szintje, másrészt az országonként eltérő jogalkotás alapján, és szabályozásaikkal befolyásolják a nemzetközi szervezetek is. Az is megfigyelhetö, hogy az utóbbi évtizedekben nemzetközi szinten rendszeresen jelennek meg újabb és újabb kategóriák, területtípusok, ami nem biztos, hogy szerencsés, mert a túl sok kategória a laikusok körében inkább káoszt teremt. Legkézenfekvőbbek a védett területek azon típusai, amelyek valamely természeti-környezeti, kulturális vagy egyéb értékeik alapján kaptak, kapnak védelmet. Ilyenek pl. Észak-Amerikában a nemzeti parkok, az állami, tartományi vagy egyéb regionális parkok, a pontosan nehezen lefordítható nemzeti emlékhelyek és nemzeti erdők. Magyarországon a védett területeknek négy típusa van, ezek az általában ismert nemzeti parkokon túl a tájvédelmi körzetek, a természetvédelmi területek és a természeti emlékek. Bonyolítja a képet, hogy - többek között természeti értékek ismertetésére, bemutatására, élvezetére - léteznek védettséggel nem járó, lehatárolt szervezeti egységek is, mint pl. a natúrparkok és a vulkánparkok, illetve a továbbiakban tárgyalandó geoparkok.

\section{A geoparkok szerepe, feladata, szervezödése}

A geoparkok létrehozásának ötlete a Nemzetközi Földtani Unió (International Union of Geological Sciences, IUGS) 1996-ban Pekingben megrendezett 30. Nemzetközi Földtani Kongresszusán merült fel. Eredetileg a címet azon földtani és őslénytani értékekkel rendelkező területek számára hozták létre, amelyek természeti örökség kategóriában pályáztak, de nem nyertek a világörökségi címért folyó versenyben. A kezdeményezés világszerte váratlanul nagy társadalmi elfogadottságra talált, és az évek során egyre több geopark jött és jön létre.

A geopark egy olyan egyértelmüen lehatárolt terület, amelynek földtudományi öröksége különösen gazdag, területén az értékesnek tekintett tájelemek többsége földtani-felszínalaktani érdekességet, különlegességet jelentő geotóp, de vannak ökológiai és kulturális szempontból értéket képviselő tájelemei is (ugyanakkor nem feltétel ezen értékek kimagasló nemzetközi jelentősége). A földtudományi értékekben való gazdagság tehát szükséges feltétel, ám ennek ellenére a geoparknak alapvetően nem a területén lévő geotópok jogi értelemben vett természetvédelme a célja, hanem a területfejlesztés, környezetük fenntartható társadalmi-gazdasági fejlődésének elősegítése, mégpedig elsősorban a földtudományi értékekre alapozott geoturizmus pozitív gazdasági hatásain keresztül. Ismételten hangsúlyozni kell tehát, hogy a geopark nem egy újabb természetvédelmi kategória, bár akár az egésze, akár egyes részei lehetnek védelem alá helyezett 
területek, viszont kiemelt célja az értékmegőrzés (KISs G. - HoRváth G. 2006). A geoparkot valamely erre a célra létrejött szerveződés irányítja, amely eredményesebben tudja megvalósítani ezt az értékmegőrzést, mintha az egyes földtudományi helyszíneket külön-külön kezelnék. A geoparkok jelentős területfejlesztő hatása különösen olyan kedvezőtlen adottságokkal rendelkező, vagy korábban jelentős gazdasági tevékenységet folytató, ám mára „depresszióssá” vált térségekben lehet jelentős, amelyek ugyanakkor földtudományi értékeik miatt számottevő geoturisztikai potenciállal rendelkeznek. A geoparkok létrehozásának további célja, illetve eredménye még a helyi lakosság értéktudatosságának növelése, a földtudományi ismeretek terjesztése, valamint a látogatók környezeti szemléletének formálása is. A lényeg tehát a földtudományi értékmegőrzés és a fenntartható területfejlesztés egyidejü megvalósítása.

A geoparkok létrehozása általában alulról, a helyi szervezetektől kiinduló kezdeményezés, a helyi erők és intézmények - beleértve különösen a helyi vállalkozókat - együttmüködésén, szándékán alapul. Látni kell azonban, hogy egyre több geopark létrejötte valamely természetvédelmi szervezet (pl. nemzeti park) „ernyője” alatt történik.

A „geoparkmozgalom” 2000-ben az Európai Geoparkok Hálózata (European Geoparks Network) megalapításával kezdődött. Négy „alapító” tag volt: a görög sziget, Leszvosz „megkövesedett erdeje”, a franciaországi Felső-Provence földtani rezervátuma, a németországi Eifel-hegység vulkáni területe (2. kép) és a délkelet-spanyolországi Maestrazgo „Kulturális Park” földtanilag érdekes vidéke. Jelenleg 24 európai ország 73 geoparkja alkotja a hálózatot (KorBÉLY B. 2007; 1. ábra). Közben megalakult a Globális Geopark Hálózat (Global Geopark Network, GGN; 2. ábra) is, amely már az Európán kívüli geoparkokat is felölelte (Eder, W. 1999, Henriques, M. H. - Brilha, J. 2017). Ez az UNESCO hivatalos hálózata lett, és ma már az Európai Geoparkok Hálózata minden tagja egyúttal a Globális Geopark Hálózatnak is tagja. A 38 országban megtalálható UNESCO geoparkok száma 140, közülük 37 kínai. Magyarországot két geopark képviseli: a régebben alapított, magyarországi és szlovákiai területeket egyaránt felölelő Novohrad-Nógrád Geopark (a Föld első határon átnyúló geoparkja) és az újabban létrehozott Bakony-Balaton Geopark.

\section{A geoparkká válás menete}

Az UNESCO Geopark Hálózatba csak nemzetközi pályázati eljárás során lehet bekerülni, szigorúan előírt feltételek teljesítése esetén. A geopark cím elnyeréséhez tehát előre 


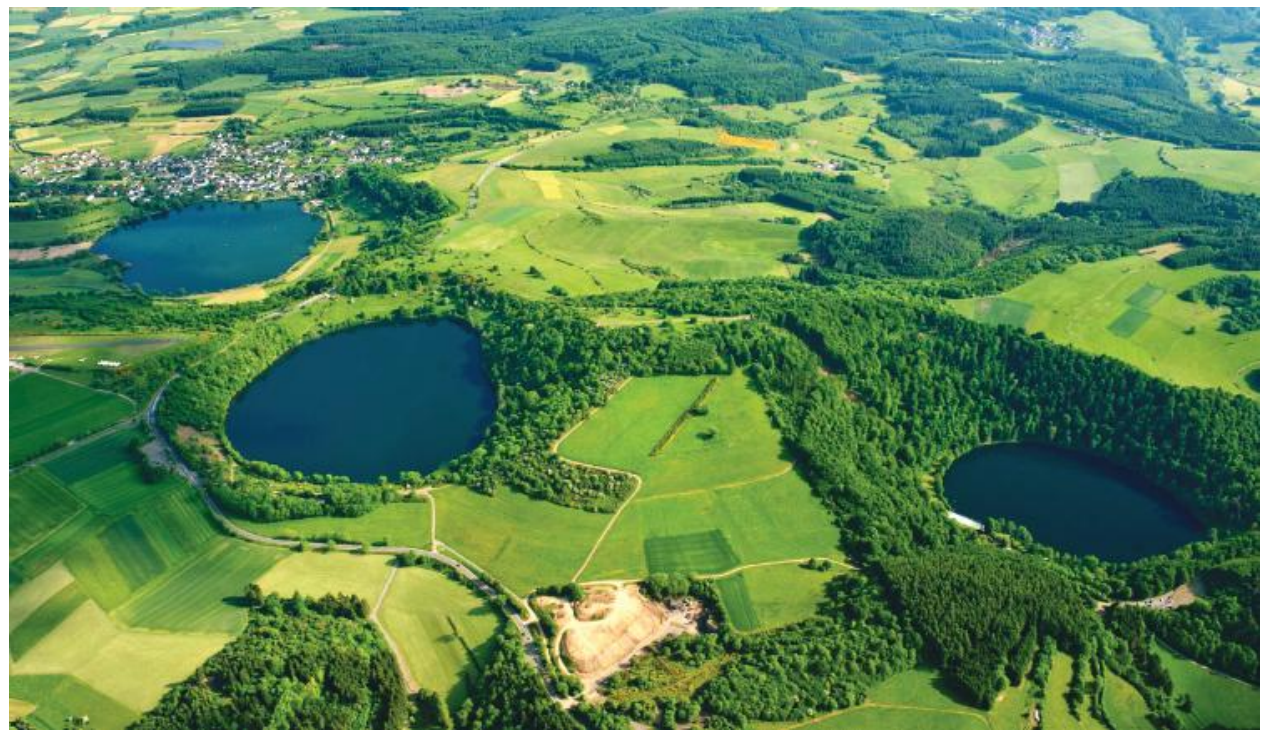

2. ábra. Maarok a Vulkaneifel Geoparkban (forrás: https://www.eifel.info/natur/unesco-geopark-vulkaneifel)

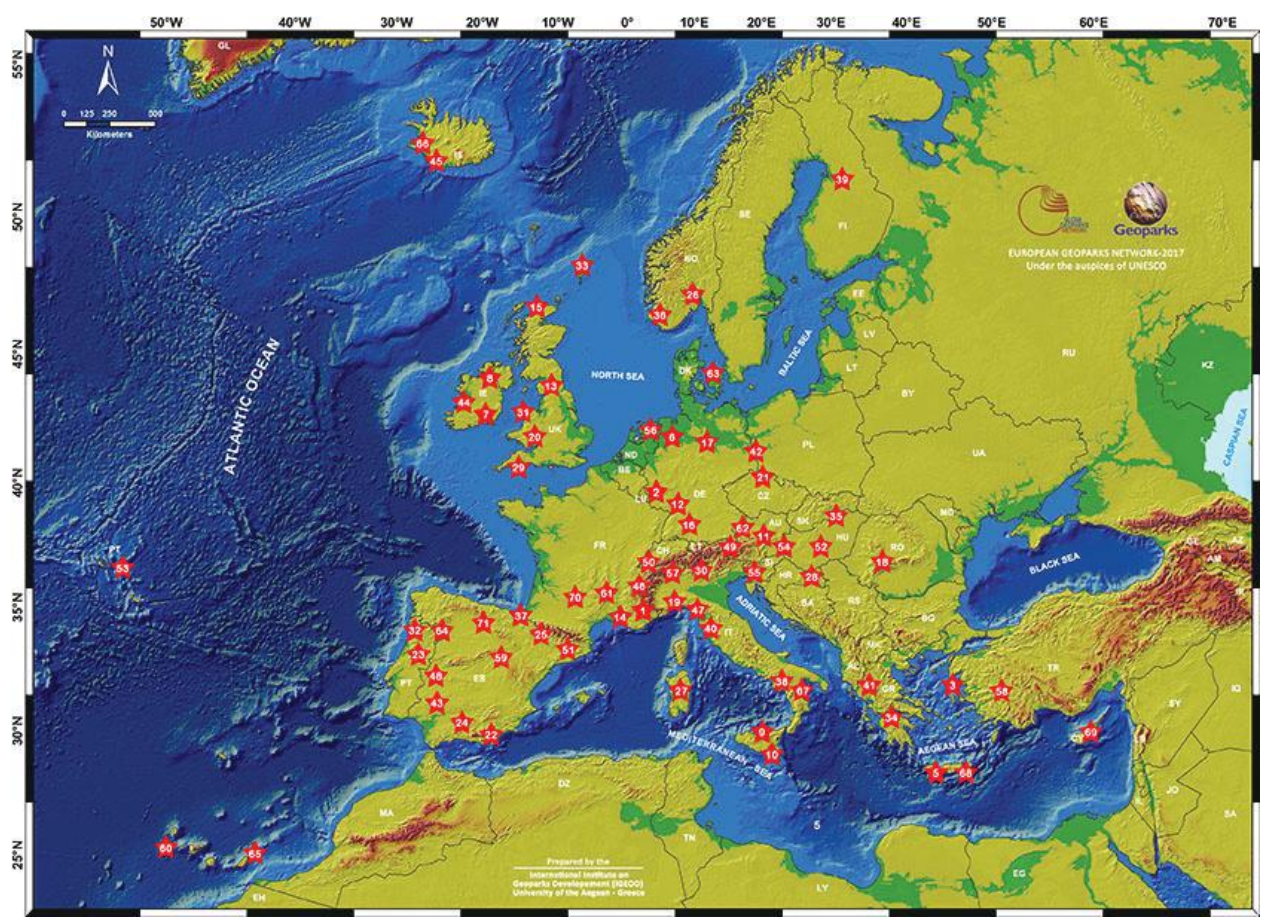

3. ábra. Az Európai Geoparkok Hálózatának tagjai (forrás: http://www.europeangeoparks.org/?page_id=168) 


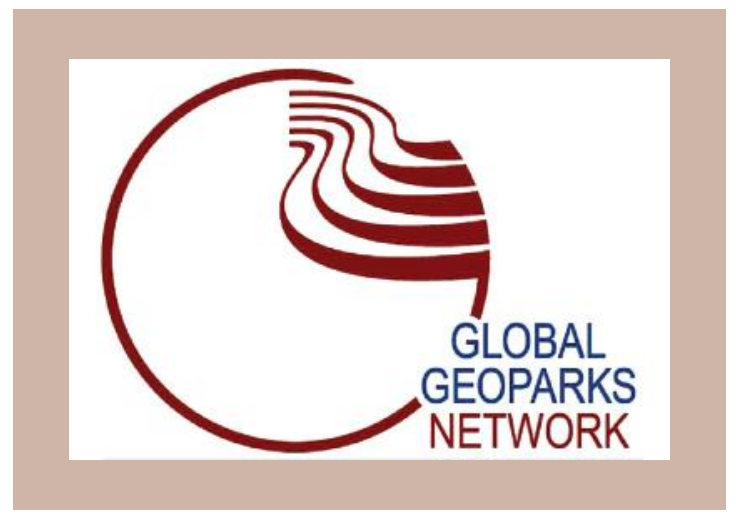

4. ábra. Az UNESCO Globális geopark Hálózat logója (forrás: http://globalgeoparksnetwork.org/)

megadott szempontrendszer alapján pályázati anyagot kell összeállítani. Mivel értelemszerüen nem minden pályázó nyerheti el a címet, csak kb. évi 10-12, ezért több országban létrehoztak az említett hálózatoktól független, különösen a belföldi geoturizmust fellendítő ún. nemzeti geoparkokat is. Magyarországon jelenleg folyik az a törvényalkotási folyamat, amely lehetővé teszi majd nemzeti geoparkok létrehozását, természetesen az UNESCOgeopark cím elnyeréséhez szükségeshez hasonlóan szigorú feltételek teljesülése esetén. Erről majd a Magyar Geopark Bizottság dönt, mint ahogy arról is, adott esetben továbbítja-e egy UNESCO-geopark várományos pályázatát a nemzetközi szervezet illetékes bizottságához.

Ami a pályázati feltételeket illeti, egy a címre pályázó geoparknak egyértelműen meghatározott határokkal kell rendelkeznie és elengedően nagy méretűnek kell lennie ahhoz, hogy a helyi gazdasági fejlődést biztosítani legyen képes. A geopark müködtetésére valamilyen országos, regionális vagy helyi hatáskörű szervezetet kell létrehozni, amelyben messzemenően biztosítani kell a helyi közösségek részvételét (persze már korábban létezett szervezet is lehet „gazda”). Ennek a szervezetnek kell majd benyújtania a geopark cím elnyerésére irányuló pályázatot. A pályázathoz számos alapvető dokumentumot kell elkészíteni, amelyeknek tartalmazniuk kell többek között a leendő geopark területe és környezete természeti, társadalmi és gazdasági viszonyainak jellemzését, a terület értékeinek, különösen geotópjainak átfogó kataszterét, minősítését, a leendő arculat kialakításának tervét, a tervezett geopark fenntartható fejlesztési politikáját, a geoturizmus lehetőségeinek részletes kibontását stb. Mindez természetesen szakemberek, üzletemberek, helyi döntéshozók bevonását, aktív közreműködését igényli és csak az érdekelt felek széleskörű együttműködésével valósítható meg. 
Megjegyzendő még, hogy ha a benyújtott dokumentumok alapján a leendő geopark bekerül a várományosok közé, akkor az UNESCO bíráló bizottsága által felkért szakértők helyszíni szemlét is tartanak, és annak tapasztalatai is a döntéshozók elé kerülnek. Sikeres nemzetközi pályázás esetén a cím öt évre nyerhető el. Pályázni, a címet elnyerni sem könnyü, de talán még nehezebb a müködtetés. Hiszen - részben a helyi közösségekre alapozva, részben újabb pályázatok útján - elő kell teremteni a fejlesztési tervek megvalósításához szükséges finanszírozást, eleget kell tenni a kezelési tervben vállalt feladatoknak, meg kell valósítani a területfejlesztést elősegítő intézkedéseket, de úgy, hogy közben biztosítani kell a természetvédelmi kezelés kötelmeit (pl. mivel földtani értékek károsításához egy geopark semmilyen körülmények között nem járulhat hozzá, ezért tilos a képződmények - köztük ősmaradványok, ásványok stb. - egyébként bevételi forrásnak tűnő árusítása). Az öt év lejártakor szigorú felülvizsgálati folyamat zajlik le, és a geopark nem megfelelő müködése esetén az elnyert cím akár vissza is vonható.

\section{A geoparkok oktatási jelentősége}

A geoparkok gazdag geoturisztikai kínálatukkal elsősorban a földtani folyamatok és látványos felszínalaktani képződmények iránt érdeklődőket vonzzák, de megfelelő attraktivitás esetén mind az iskolai tanulókat, mind a laikus nagyközönséget képesek megszólítani. Geotópjaik felkeresése kitűnő lehetőséget biztosít a földtudományi értékek bemutatására, népszerüsítésére, védelmük fontosságának hangsúlyozására. A jól kiépített, didaktikusan kialakított ismertető és magyarázó táblákkal ellátott egyes látogatóhelyek, a legértékesebb, leglátványosabb helyszíneket összefüző tanösvények, a geopark területén található kulturális örökségek és különösen a látogató- és oktatóközpontok felkeresése kiváló lehetőséget ad a tanórán kívüli tanításra és tanulásra. Jól megszervezett rövidebb időtartamú természetismereti és geotúrák mellett hosszabb erdei iskolai programok, geotáborok segíthetik az ismeretek magas fokú elsajátítását. Mindezek megvalósítását mindkét magyarországi geopark igyekszik elősegíteni. A BakonyBalaton Geoparkban évek óta folyik geotúra-vezetők képzése, és a legsikeresebb túravezetök szinte minden héten meghirdetnek - elsősorban a családok és a tanulók számára - különböző geotópok felkeresését célzó nyilvános geotúrákat. Természetesen a geoparkokon kívül is vannak értékes, felkeresésre érdemes, a földrajzoktatásba bevonható geotópok, de a geoparkok szervezettségükkel, kiépített infrastruktúrájukkal, számos - több nyelven is elérhető - tájékoztató, ismeretterjesztő kiadványukkal, a tanulócsoportok szervezett fogadásával és vezetésével különösen hozzájárulhatnak a földrajztanár munkájának eredményesebbé tételéhez. 
(E téma kapcsán még megjegyzendő, hogy a Magyarhoni Földtani Társulat minden évben, általában október első hétvégéjén meghirdeti az ún. Geotóp Napokat, amikor az ország számos helyén nyílik lehetőség szakértők vezetésével különböző érdekes és értékes geotópok szervezett végigjárására; erre érdemes a földtudományok iránt érdeklődő diákok figyelmét felhívni, esetleg azon a földrajztanárnak legjobb, legérdeklődőbb tanulóival együtt részt venni. A programok a geotopnap.hu címen tekinthetők meg.)

Fenti írás célja a geoparkok fogalmának, jelentőségének, történetének megismertetése volt. A későbbiekben majd igyekszünk bemutatni a két magyarországi geopark legjelentősebb geotópjait is.

\section{Irodalom}

Anglin, R. M. - Morris, L. E. 2016: The mystery of John Colter: the man who discovered Yellowstone. Rowman \& Littlefield Publishers. 274 p.

Burek, C. V. - Prosser. C. D. (szerk.) 2008: The history of geoconservation. - The Geological Society. Special publication 300. London. 311 p. https://doi.org/10.1144/SP300.0

EDER, W. 1999: "UNESCO GEOPARKS" - A new initiative for protection and sustainable development of the Earth's heritage. - Neues Jahrbuch für Geologie und Paläontologie Abhandlungen 214. 1-2. pp. 353-358. https://doi.org/10.1127/njgpa/214/1999/353

Henriques, M. H. - Brilha, J. 2017: UNESCO Global Geoparks: a strategy towards global understanding and sustainability. - Episodes 40. 4. pp. 349-355. https://doi.org/10.18814/epiiugs/2017/v40i4/017036

Kiss G. 1996: A földtudományi értékekről és védelmük lehetséges módjairól. - Földrajzi Közlemények 120. 1. pp. 3-14.

Kiss G. - Horváth G. 2006: A földtudományi értékek megőrzésének új eszközei: a geoparkok. - In: Kókai S. (szerk.): Földrajz és turizmus. Nyíregyháza, pp. 163-171.

KorbéLy B. 2007: Geoparkok Európában és hazánkban. - A Földgömb 9. 2. pp. 60-69.

Lotz, J. - Schürmann, J. 1998: A világ természeti és kultúrkincsei. Észak-Amerika és Mexikó. - Alexandra Kiadó, Pécs. 320 p.

TARDY J. - SzARVAS I. 2008: A Yellowstone-tól a geoparkokig. Új esély a földtudományi értékek védelmére.

- Természet Világa 139. Különszám 2. pp. 9-13.

Tardy J. - T. Draskovits Zs. - Szarvas I. 2006: A földtani és felszínalaktani értékek védelme Magyarországon - történeti áttekintés, tények és lehetőségek. - A III. Magyar Földrajzi Konferencia Tudományos Közleményei. 16 p. http://geography.hu/mfk2006/pdf/Tardy\%20J\%E1nos.pdf

Wimbledon, W. A. P. 1996: Geosites - a new conservation initiative. - Episodes 19. 3. pp. 87-88.

Wimbledon, W. A. P. - Smith-Meyer, S. (szerk.) 2012: Geoheritage in Europe and its conservation. - ProGEO. 405 p. UNESCO Global Geoparks 2016. - UNESCO, Párizs. 20 p. http://www.globalgeopark.org/ UploadFiles/2016_2_16/UNESCO\%20Global\%20Geopark\%20Brochure.pdf 